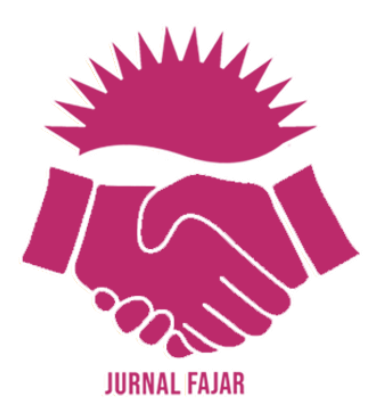

\title{
PemberdayaAn Generasi Muda Melalui Pelatihan WIRAUSAHAWAN BARU DI DAERAH UJUNG HARAPAN BAHAGIA BABELAN BEKASI*
}

\author{
Aep Kusnawan, Nurazijah \\ Universitas Islam Negeri Sunan Gunung Djati Bandung \\ E-mail:aep_kusnawan@uinsgd.ac.id \\ 10.15408/jf.v20i2.20603
}

\begin{abstract}
:
The younger generation as the workforce with the largest population in the Ujung Harapan Region, Bekasi, Indonesia. Their enthusiasm for entrepreneurship has grown, but generally they do not have sufficient knowledge and skills about it. As a result, entrepreneurship often occurs. This training was carried out to train these new entrepreneurs on how to start entrepreneurship properly and correctly, improve their entrepreneurial abilities and explore the factors that hinder and support entrepreneurship. This training uses the Demonstration method. The results of the training showed that the implementation of the training carried out attracted the attention of the participants, then raised their entrepreneurial spirit to be better, because of this training the participants gradually understood where the causes of their entrepreneurship were hampered. So it can be concluded that the training held was quite successful.
\end{abstract}

Keywords: Young Generation, Training, Entrepreneur

*Diterima 28 April 2020, Revisi 22 Mei 2020, Diterbitkan 30 Juni 2020.

Fajar: Media Komunikasi dan Informasi Pengabdian Kepada Masyarakat Vol 20 No 2 (2020) - 129 


\section{Abstrak:}

Generasi muda sebagai angkatan kerja dengan populasi terbesar di Daerah Ujung Harapan Bekasi Indonesia. Semangat mereka berwira usaha telah tumbuh, namun umumnya tidak memiliki bekal pengetahuan dan keterampilan yang cukup tentang itu. Akibatnya sering terjadi mengalami kegagalan berwirausaha. Pelatihan ini dilaksanakan untuk melatih para wirausahawan baru tersebut tentang cara memulai wirausaha dengan baik dan benar, meningkatkan kemampuan wirausaha mereka serta menggali faktorfaktor yang menjadi menghambat dan mendukung dalam kewirausahaan. Pelatihan ini menggunakan metode Demonstrasi. Hasil pelatihan menunjukkan bahwa pelaksanaan pelatihan yang dilaksanakan sangat menarik perhatian peserta, kemudian membangkitkan semangat wirausaha mereka untuk lebih baik, karena adanya pelatihan ini para peserta sedikit demi sedikit paham dimana letak penyebab terhambatnya kewirausahaan mereka. Sehingga dapat disimpulkan bahwa pelatihan yang diadakan ini cukup berhasil.

Kata Kunci: Generasi Muda, Pelatihan, Wirausaha 


\section{Pendahuluan}

Setiap orang dalam hidupnya pernah berlatih. Pelatihan dilakukan seiring dengan kehidupan yang terus berubah. Perubahan yang terjadi Sebagian karena pertumbuhan alamiah. Namun tidak sedikit perubahan terjadi karena sebgian dari hasil kreativitas manusia dalam memelihara alam lingkungannya. Manusia berpikir, berkreasi dan melakukan inovasi, sehingga menghasilkan berbagai penemuan baru. Setiap penemuan baru, memiliki imbas perubahan dalam kehidupan social. Perubahan yang terjadi menuntut kesiapan perubahan pula pada tiap orang. Penemuan terjadi setiap hari, maka perubahan pun terjadi setiap hari. Sehingga amatlah wajar, jika perubahan yang terjadi pada masa kini dan masa yang akan datang, akan menjadikan setiap orang menjadi sebagai peserta pelatihan seumur hidup. Karena setiap orang harus berubah untuk mengatasi perubahan. Oleh karena itu, perubahan menjadi alasan, sekaligus menjadi tujuan dari kegiatan Latihan yang diselenggarakan.

Pelatihan bukanlah merupakan tujuan akhir dari suatu program, karena tidak setiap masalah atau kekurangan dapat diselesaikan dengan pelatihan. Ada masalah yang dapat dipecahkan dengan pembinaan, dan ada pula yang dapat dipecahkan dengan pelayanan.

Dengan demikian, pelatihan hanyalah salah satu diantara sekian banyak alternatkive pemecahan masalah. Agar alternatif pemecahan yang ditawarkan tepat, maka diperlukan studi atau penelitian.

Penelitian akan menjawab dibutuhkan atau tidaknya pelatihan. Dengan kata lain, kebutuhan pelatihan. Dengan kata lain, kebutuhan pelatihan berasal dari adanya kekuarangan, yang kemudian perlu diisi dengan kegiatan pelatihan. Adanya kebutuhan akan pelatihan berarti pula adanya harapan perubahan, dari keadaan atau prestasi yang di bawah standar, paling tidak agar menjadi standar.

Oleh sebab itu, upaya penemuan kebutuhan yang tepat dirasakan penting. Hal itu agar pelatihan yang akan diadakan dapat menjawab kebutuhan peserta dan membantu penyelesaian masalah yang dihadapinya.

Penemuan kebutuhan pelatihan dapat dilakukan melalui sebuah studi yang dinamakan Studi Penjajagan Kebutuhan Pelatihan (SPKP). SPKP adalah suatu studi yang diadakan dalam rangka mengumpulkan dan menganalisis gejala-gejala atau keterangan yang dapat menunjukan adanya kekurangan dalam hal keterampilan, pengetahuan, sikap dari calon peserta pelatihan, sehingga diharapkan dapat memenuhi kebutuhan pelatihan yang cocok dengan masalah yang sedang dihadapi. Dengan kata lain SPKP menanyakan atau menemukan menu apa yang dibutuhkan.

Dengan demikian, SPKP memiliki kegunaan sebagai upaya mengumpulkan informasi yang berkaitan dengan pengetahuan, dan prilaku peserta saat ini yang diperlukan untuk merealisasikan tugas. Ia juga berguna dalam mengidentifikasi gap antara pengetahuan, keterampilan, dan prilaku saat ini dengan kebutuhan 
akan pengetahuan, dan prilaku yang seharusnya untuk melakukan tugas. Di samping ia juga dapat menjadi acuan dalam merumuskan tujuan latihan da nisi materi pelatihan.

Oleh karena itu, adanya SPKP diharapkan dapat menemukan kebutuhan yang dirasakan. Dengan begitu pelatihan yang akan diadakan dapat menjawab kebutuhan peserta. Terutama dapat membantu mereka dalam penyelesaian masalah atau kebutuhan yang dihadapinya saat ini.

SPKP sendiri dilakukan dengan sasaran untuk memperoleh beberapa hal, yaitu: Pertama, memperoleh peserta yang tepat (berkualitas) sesuai dengan tujuan. Kedua, memperoleh rumusan hasil yang akan dicapai. Ketiga, memperoleh gambaran tentang masalah dan hambatan yang bia diatasi melalui pelatihan. Keempat, memperoleh gambaran tentang potensi dan sumber daya yang bias ditingkatkan dalam pelatihan. Kelima, memperoleh gambaran metode dan media yang sesuai bagi peseta. Keenam, memperoleh gambaran materi atau pokok-pokok bahasan pelatihan.

Salah satu yang menjadi focus kondisi saat ini adalah terjun kedunia entreupreneurship atau kewirausahaan, hal ini jadi pilihan menarik bagi para generasi muda. Sebagai buktinya, ada begitu banyak usaha milik anak muda yang bermunculan. Kemajuan teknologi informasi menjadi salah satu faktor pemicu meningkatnya jumlah pengusaha muda ditanah air. Ditambah lagi, pilihan menjadi seorang wirausaha memberi fleksibilitas jam kerja.

Hanya saja, meningkatnya jumlah generasi muda yang terjun kedunia wirausahaan juga diiringi dengan tingginya angka kegagalan dalam menjalankan aktivitas wirausaha. Kegagalan tersebut bisa terjadi karena para pelakunya tak mempunyai kecakapan dalam menjalankan usaha. Bahkan, tak menutup kemungkinan mereka tidak mengerti apa yang dimaksud kewirausahaan. Keadaan seperti itu, sebagaimana yang terjadi dikalangan kawula muda di daerah Ujung Harapan Bahagia, Babelan-Bekasi.

Di satu sisi wirausahawan muda ini Ujung Harapan Bahagia, BabelanBekasi dapat dipandang sebagai potensi yang cukup mengembirakan, karena hasrat berwira usaha telah tumbuh. Namun demikian, masih memerlukan upaya pendampingan maupun juga pelatihan-pelatihan untuk memberikan pembekalan kepada mereka guna meminimalisir tingkat kegagalan yang mereka biasa alami.

Untuk itu kegiatan pelatihan kewirausahaan ini dilaksanakan terhadap para wirausawawan muda di Daerah Ujung Harapan Bahagia, Babelan-Bekasi. Berdasarkan identifikasi yang ada karena masih kurangnya para pelaku usaha kecil dalam mendapatkan ilmu tentang cara berusaha dan juga permasalahan yang timbul dari latar belakang sehingga peneliti melakukan pelatihan di daerah Ujung Harapan Bahagia, Babelan-Bekasi. Sehingga dapat diterapkan dengan baik oleh para pelaku usaha kecil. 


\section{Metode}

Jenis metode pelatihan yang digunakan adalah pelatihan Demonstrasi. Suatu demonstrasi untuk menunjukkan dan merencanakan bagaimana suatu pekerjaan atau bagaimana sesuatu itu harus dikerjakan. Metode ini lebih banyak melibatkan penguraian dan cara memperagakan sesuatu melalui contoh-contoh. Metode ini sangat mudah bagi para manajer dalam mengajarkan para pegawai baru tentang berbagai aktivitas nyata melalui suatu tahap-tahap perencanaan dari "Bagaimana dan apa sebabnya" pegawai akan mengerjakan pekerjaan yang ia kerjakan. Metode ini sangat efektif, karena lebih mudah dalam menunjukkan kepada para peserta tentang bagaimana cara dalam mengerjakan suatu tugas, karena telah dikombinasikan dengan alat Bantu belajar seperti: gambar-gambar, teks materi, ceramah, dan diskusi.

\section{Hasil dan Pembahasan}

Wirausaha sebagai sebagai upaya mengenali produk baru, menentukan cara produksi baru, menyusun operasi untuk pengadaan produk baru, memasarkannya, serta mengatur permodalan operasinya. Sampai saat ini belum ada keseragaman pendapat pakar ekonomi dan bisnis dalam mendefinisikan wirausaha. Namun untuk pengertian sehari-hari dapat kita sebutkan wirausaha atau kewirausahaan adalah kegiatan usaha/bisnis yang dilakukan para pengusaha. Pengertian wirausaha juga diberikan dari sisi-sisi tertentu saja. Berikut ini adalah ringkasan beberapa pendapat dari para pakar ekonomi dan bisnis antara lain sebagai berikut:

a) Richard Cantillon menyebutkan bahwa wirausaha adalah seseorang yang menanggung risiko dalam pembelian dan penjualan.

b) Adam Smith dan Jean Baptise Say menyebutkan bahwa wirausaha adalah seseorang yang mampu menyatukan faktor-faktor produksi.

c) Jose Carlos Jarillo-Mossi menyebutkan bahwa wirausaha adalah seseorang yang mampu merasakan adanya peluang, mengejar peluang yang sesuai dengan situasi dirinya, dan percaya bahwa kesuksesan merupakan sesuatu yang dapat dicapai.

d) William H. Sahlman menyebutkan bahwa seorang wirausaha dapat saja tidak melakukan pembelian maupun penjualan, tidak pula menyatukan faktorfaktor produksi, ia bukan seorang penemu (inovator) tetapi seorang peniru. Ia tidak mempunyai bisnis sendiri tetapi menata bisnis orang lain yang di dalamnya mengandung pemanfaatan peluang dan pengambilan risiko.

Jadi, sebagaimana yang telah disebutkan disebutkan, secara singkat kita sebut saja wirausaha (entrepreneur) sebagai pengusaha mandiri. Dalam arti yang lebih luas wirausaha dapat diartikan sebagai seseorang atau kelompok orang yang mempunyai kemampuan untuk mengembangkan diri dalam kegiatan bisnis dengan memanfaatkan berbagai peluang yang ada dan mengambil risiko yang 
terkecil, sehingga dapat mencapai tujuannya. Kemampuan tersebut dapat disalurkan untuk mengelola bisnis milik sendiri atau pula dapat disalurkan untuk menata atau mengorganisasikan bisnis milik orang lain dengan imbalan tertentu.

Untuk meningkatkan kualitas dari kegiatan pelatihan ini pihak panitia melakukan evaluasi. Tujuan dari evaluasi ini adalah sebagai bahan masukan buat penyelenggara dan instruktur dalam penyelenggaraan pelatihan dimasa yang akan datang. Evaluasi tersebut dilakukan dengan cara menyebarkan kuesioner kepada peserta pelatihan. Adapun aspek yang dievaluasi meliputi materi pelatihan, instruktur, panitia penyelenggara dan evaluasi tingkat kehadiran peserta.

\section{Evaluasi Materi}

Tujuan dari evaluasi materi ini adalah untuk menilai tentang kesesuaian materi dengan kebutuhan dan harapan peserta yang menyangkut :

a. Kualitas topik bahasan

b. Kesesuaian materi dengan kebutuhan usaha

c. Kesesuaian materi dengan praktek di lapangan (tempat usaha)

Dari hasil tanggapan peserta dapat disimpulkan bahwa materi yang telah diberikan menggambarkan : $78 \%$ peserta menyatakan sangat baik, $14 \%$ peserta menyatakan baik dan $8 \%$ peserta menyatakan cukup. Dengan demikian dapat disimpulkan bahwa topik dan materi dari pelatihan Mengembangkan Sikap Kewirausahaan Bagi Pengusaha Kecil ini sudah sesuai dengan harapan dan kebutuhan peserta.

\section{Evaluasi Instruktur}

Maksud dan tujuan dari evaluasi instruktur ini untuk menilai kualitas instruktur dalam menyampaikan dan mengemas materi selama pelatihan. Adapun unsur-unsur yang menjadi penilaian adalah :

a. Penguasaan dan penyampaian materi

b. Kemampuan meningkatkan motivasi dan keterampilan peserta

c. Wawasan dan penampilan

Dari hasil penilaian yang di lakukan oleh peserta pelatihan menunjukkan hasil sebagai berikut, $80 \%$ peserta menyatakan sangat baik, $12 \%$ peserta menyatakan baik dan $8 \%$ peserta menyatakan cukup. Dengan demikian dapat disimpulkan bahwa kualitas instruktur dalam mengemas dan menyampaikan materi kepada peserta sudah sesuai dengan harapan peserta. 


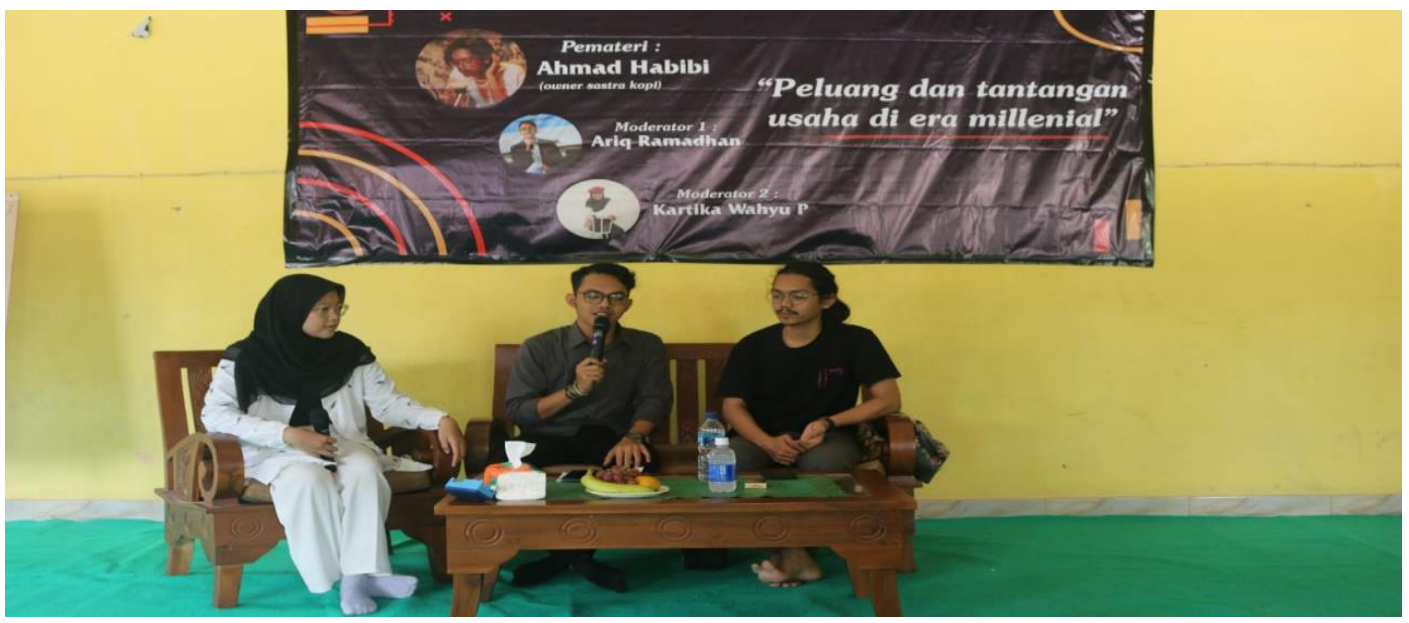

Gambar 1. Ketika pemaparan materi

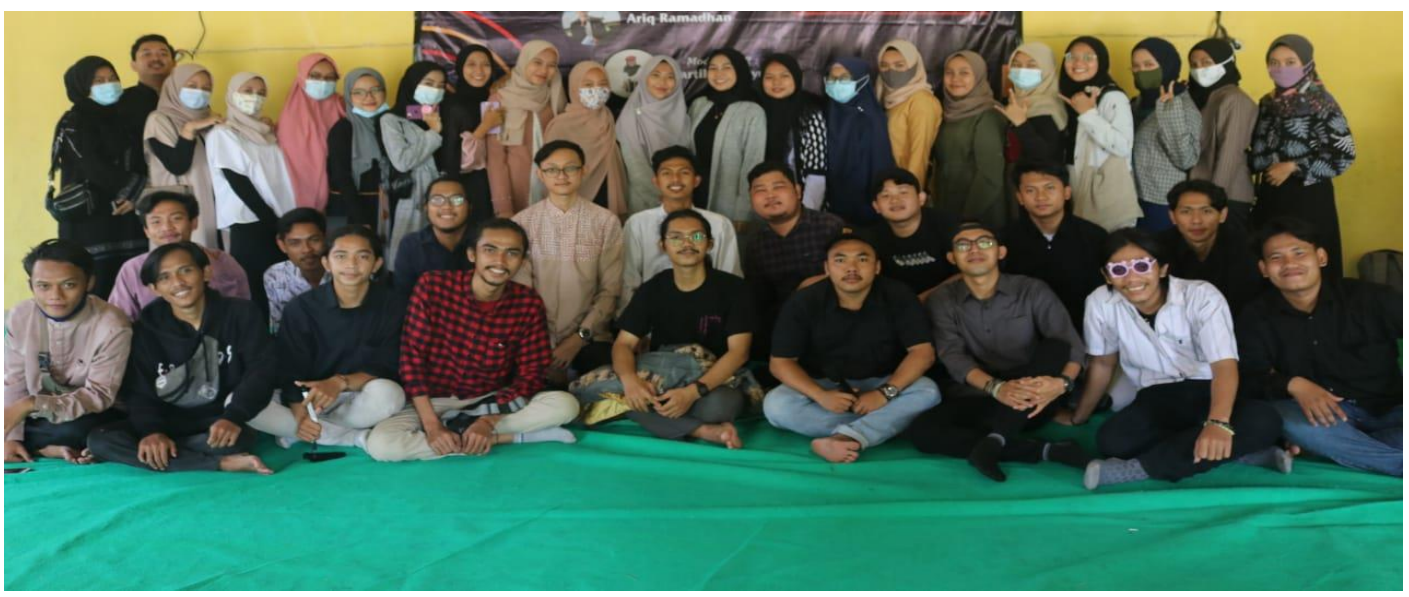

Gambar 2. Dokumentasi peserta, pemateri dan panitia.

\section{Kesimpulan}

Terjun ke dunia entreupreneurship atau kewirausahaan kini jadi pilihan menarik bagi para generasi muda. Sebagai buktinya, ada begitu banyak usaha milik anak muda yang bermunculan. Kemajuan teknologi informasi menjadi salah satu faktor pemicu meningkatnya jumlah pengusaha muda ditanah air. Ditambah lagi, pilihan menjadi seorang wirausaha memberi fleksibilitas jam kerja.

Hanya saja, meningkatnya jumlah generasi muda yang terjun kedunia wirausahaan juga diiringi dengan tingginya angka kegagalan dalam menjalankan aktivitas wirausaha. Kegagalan tersebut bisa terjadi karena para pelakunya tak mempunyai kecakapan dalam menjalankan usaha. Bahkan, tak menutup kemungkinan mereka tidak mengerti apa yang dimaksud kewirausahaan . maka dari itu dengan adanya pelatihan kewirausahaan ini sedikit memudahkan para 
pengusaha pemula dan bisa sedikit memecahkan beberapa pertanyaan yang berada dibenak para peserta.

\section{Referensi}

[1] Bungin, B. (2007). Penelitian kualitatif. Jakarta: Prenada Media Group

[2] Hendriani, Susi. (2012). Repository university of Riau. Laporan kegiatan kewirausahaan bagi mitra binaan PT. Jamsostek cabang Pekanbaru

[3] Dwi, Rianti. (2003). Kewirausahan dari Sudut Pandang Psikologi Kepribadian. Jakarta: Gasindo

[4] Kusnawan, Aep dan Aep Sy Firdaus (2009), Manajemen Pelatihan Dakwah, Jakarta: Rineka Cipta.

[5] Kusnawan, Aep dan Yusril PN, "Pemberdayaan Asset Tenun Bipolo Melalui Metode Marketing Mix Training untuk Menumbuhkan Kemandirian Masyarakat Desa" Al-Khidmat: Jurnal Pengabdian kepada Masyarakat, Vol.3 No.2 Tahun 2020.

[6] Saydam, Gouzali (2006), Built in Training: Jurus Jitu Mengembangkan Profesionalisme SDM, Bandung: Rosda.

[7] Suryana. (2011), Kewirausahaan. Jakarta: Salemba Empat

[8] Suryana, Agus (2005), Seni Mendesai Pelatihan, Jakarta: Progress

[9] Suyatno Purnama, Chamdan. (2010). Motivasi dan Kemampuan Usaha dalam Meningkatkan Keberhasilan Usaha Industri Kecil (Studi Pada Industri Kecil Sepatu di Jawa Timur).Jurnal Manajemen dan Kewirausahaan, pp. 177-184.

[11] Sudjana, D (2007), Sistem E Manajemen Pelatihan Teori dan Praktik, Bandung: Falah Production. 